\title{
nature
}

\section{Reforms on a knife edge}

Frustration among French researchers at an apparent slowing down in promised reforms threatens to undermine an essential process. A less abrasive attitude on the government's part is essential.

rance faces a unique opportunity to modernize its science base. Its scientific community — previously suspicious of reform is not only clearly open to change but actively demanding it. There is a bristling optimism in the air, reminiscent of the high hopes that accompanied the election of President François Mitterrand in 1981. The then science minister, Jean-Pierre Chevènement, allowed this enthusiasm to express itself by organizing a whirlwind series of colloquia, the outcome of which was a white paper laying the foundations for a rejuvenation of French science during the 1980s.

Claude Allègre, the current minister of national education, research and technology, is well placed not only to match Chevènement's achievements but to surpass them. As a prominent Earth scientist with considerable administrative and political experience, his grasp of what science is about, and his vision of what it could deliver to society, probably surpasses that of any of his predecessors. And with a superministry responsible for virtually every aspect of science and technology, he has the means to put this vision into practice.

Allègre has already moved swiftly to redress one of the fundamental problems facing French science, its ageing population of researchers. The infusion of thousands of new posts - and a promise to put young researchers at the heart of all of his policies - is a wise step that should provide handsome benefits in the long term. His goal of reducing bureaucracy is also admirable. Continuing in the same vein, Allègre has also made it clear that he wants to put high-level research back into the universities, where it can nourish entire generations of students, consistent with his broader goal of injecting the benefits of science into all corners of society.

In short, French science has at its helm a competent captain, who is charting a course that few would dispute is enlightened. Why, then, is discontent rumbling in the ranks of the scientific community, many of whom feel that the ship of reform, having raced down the boat-slip, is now idling in harbour instead of steaming out to sea (see page 8 )?

Some of this impatience is unfair. French science, with its massive research organizations and technological programmes, is not an agile speedboat but a supertanker that needs time to turn. Changing direction, however, and more importantly steaming ahead, also requires having the crew on one's side. Past science ministers have often been paralysed by the fact that attempts to shake French science out of its leisurely cruise usually end in mutiny. Allègre has made it clear that he is having none of this - and deserves credit for the courageous and forthright way in which he has denounced the failings of the system and the conservative obstacles to reform.

But Allègre's repeated attacks on the system have become monotonous, and, by provoking a stubborn defensiveness in others, he risks contributing to the very conservatism he has set out to overcome. Moreover, while Captain Allègre's vision of where he wants to go may be clear, winning the support of the crew also demands explaining how exactly he intends to get there. So far, his ministry has failed to do this adequately, and researchers feel insecure as a result. Allègre must not only clarify his intentions but also involve the scientific community more openly in dialogue on how these can be achieved. Perhaps he would do well to reflect on la méthode Chevènement.

\section{Lewis and Clark, lost in the wilderness?}

\section{The abandonment of a privately managed satellite should encourage sharper thinking about such ventures.}

T he demise of the Lewis and Clark satellite projects, which the US National Aeronautics and Space Administration (NASA) had hoped would help to usher in a new era of commercial Earth observation from space (see page 5), could be seen as a mark against the space agency's 'better, cheaper, faster' way of doing business. But that interpretation is too glib. Large, expensive satellites fail, too, and other low-cost projects - such as the Lunar Prospector now circling the Moon - appear to be doing well.

The post-mortem reports on the two satellites should help to determine whether more time or money would have improved either mission's chances of survival. While waiting for these reports, however, NASA needs to examine its often confused policy toward 'commercialization' - the introduction of market forces into the management of space missions.

Lewis and Clark were far from being market-driven ventures. They were NASA's idea, developed with NASA funding. At the time they were conceived, a genuinely private remote-sensing industry had just come into being, and some start-up companies complained that government involvement was unnecessary. Four years later, the fledgling industry has grown to include major companies, such as Lockheed-Martin and Kodak. But its prospects are still uncertain. The first remote-sensing satellite built with private money - the EarlyBird 1, owned by Col- orado-based Earthwatch, Inc. — lost radio contact with the ground shortly after its launch in December.

Part of the Lewis and Clark experiment was to turn over most dayto-day management decisions to the satellites' private constructors. But this hands-off policy appears to have backfired for NASA. Neither contractor - both experienced companies - succeeded, perhaps because the missions were underfinanced in the first place.

Despite such failure, NASA leaders and many in Congress continue to insist that the private sector can work miracles, and that commercial projects - or even quasi-commercial ones - are by definition better than those run by the government. Commercial space advocates in Congress have been pushing NASA to rely more on Earth science data furnished by the private sector, even though those data do not yet exist. And the agency has reserved substantial room on the space station for customers who may not, in the end, appear.

As they venture into the wilderness of commercial activity, space policy-makers should take care not to imagine markets into being. Outside advice will be most welcome: to its credit, NASA has recently organized a panel of Wall Street advisers to help it to devise a strategy for commercialization, and to sort wishful thinking from cold economic analysis. A small step for the agency; a big step for the future of space missions. 